\title{
Where Are the Girls?
}

\section{Gender Trends in Juvenile Crime}

\author{
Prof. Revital Sela-Shayovitz \\ David Yellin Academic College and the Hebrew University \\ Gnessin 13/6, Givatayim, Israel \\ Tel: 972-528-653322Ｅ-mail: revita128s@gmail.co.il
}

Received: August 15, 2016 Accepted: September 24, 2016 Published: September 25, 2016

doi: 10.5296/jsss.v4i1.9891 URL: http://dx.doi.org/10.5296/jsss.v4i1.9891

\begin{abstract}
There is growing evidence that female rates of criminal nonlethal violent offending have increased during the 1990s. However, the debate regarding whether the gender gap in violence is closing is ongoing. This paper examines trends in juvenile violent offending in Israel between the years 1996 and 2012. The findings indicate that female-to-male offending rate ratios have increased over time for simple assaults, aggravated assault and carrying a knife. Moreover, the closing of the gender gap among young minors (ages 12-14 years) principally results from the increase in female rates of offending, which is greater than the rise in male rates of offending. These findings are discussed in the context of existing research on the gender gap in the perpetration of violence with reference to future directions in research.
\end{abstract}

Keywords: Gender violence, Youth violence, Crime rates, Juvenile delinquency, Crime policy

\section{Introduction}

Rates of violent crime are not random or unpredictable. Rather, they are deeply embedded in the core patterns of social change at a given period (Sela-Shayovitz, 2009). Recently, trends of female violent crime have received increased attention. Indeed, there is growing evidence that female rates of nonlethal violence have climbed over the last decades (Gavazzi \& Chesney-Lind, 2006; Lauritsen et al., 2009; Morse, 2002; Schaffner, 1999; Steffensmeier et al., 2005, 2006). An examination of official police data in the United States has showed that 
between the years 1980 and 2000 female rates of arrests have increased for simple assault from $21 \%$ to $33 \%$, and from $15 \%$ to $24 \%$ for aggravated assault. The increase in the violent crime index (i.e., homicide, forcible rape, robbery, and aggravated assault) was from 10 to 19 percent. In addition, female detentions in the United States have increased by $98 \%$ between the years 1991 and 2003 (Steffensmeier et al., 2005).

However, gender gap trends in violent crime in official police data may be biased, since they reflect both changes in criminal behaviors and policy practices (Steffensmeier et al., 2006). Nevertheless, gender patterns of violent offending as registered by the National Crime Victimization Survey compared with uniform crime data in the United States indicate that the trends showing narrowing gender gaps were similar in the two data sources. These trends in gender gaps mainly resulted from drops in male rates of offending rather than from increases in female rates of violent offending (Lauritsen et al., 2009).

In a similar vein, an analysis of the involvement of women in violent behavior in Canada between the years 1986 and 1993 showed that the number of young females charged with offenses dramatically increased by 250 percent (Artz, 1998). The rise in recorded criminal acts committed by girls in the Netherlands increased by $48 \%$ between the years 1998 and 2003 (Eggen et al., 2005). In Australia, females rates for aggravated assault increased by $61 \%$ and for assault by 19\% during the period 1996 to 2003 (Bricknell, 2008). Nevertheless, the debate regarding the gender gap in violent offending persists and is far from settled. Some scholars claim that the gap between females and males is mostly characterized by stability (Steffensmeier, 1993; Steffensmeier et al., 2005, 2006) while others argue that it is closing over time (Heimer, 2000; Lauristen et al., 2009; O’Brien, 1999).

To date, only a few studies have focused on gender trends in violence and these have been conducted primarily in the United States. Therefore, further research is essential in order to gain a deeper understanding of the subject. This paper aims to contribute to the existing literature by extending its focus to trends in juvenile violent offending in Israel. Furthermore, most studies have not analyzed gender variations associated with the age of offenders whose first criminal records were filed for violent offenses. The present study seeks to shed light on this aspect as well.

\subsection{Theoretical Framework}

Several theoretical hypotheses have been offered regarding the increase in female violence. The liberation hypothesis is based on a feminist criminology perspective which proposes that social changes in gender roles and norms will open a window of opportunity for female criminal activity (Adler, 1975; Simon, 1976; Smart, 1976). Accordingly, this hypothesis assumes that changes in gender-role expectations together with the lessening in parental control have led to a greater freedom for females and increased participation in the public sphere. These, in turn, increased the involvement of women in violent behavior. Young females tend to adopt male patterns of assertiveness and competitiveness that "masculinize" their behavior. For example, they adopt words and phrases with harsh and coarse linguistic formulations (Artz, 1998). Thus, the rise of female involvement in violent crime largely reflects the social structure of gender roles and expectations. Another important aspect of the 
liberation hypothesis makes reference to the influence of the popular media on female violent behavior. During the last two decades there has been an escalation in the number of messages produced by the entertainment media and movies which depict and even glorify female violent activity (e.g., "Charlie's Angels," "Kill Bill"). These messages have an influence on gender-role expectations and may amplify attitudes toward and perceptions of gender equality in violent behavior (Hall, 2004; Lauritsen, et al., 2009; Steffensmeier et al., 2005, 2006).

The strain-violence hypothesis suggests that social changes in the family structure together with economic pressures and a dysfunctional community have led to the increase in female violence. This perspective is based on the "general strain theory" (Agnew, 1992) that highlights the influence of macro- and micro-level pressures on the development of antisocial behavior. Accordingly, stressful life events and a disorganized community with social structures that block opportunities are key antecedents to deviant youth behavior (Agnew, 1992; Agnew and White 1992). Studies show that family support appears to be a mediator between social and economic distress, and juvenile delinquency (Agnew 2001; Almgren, et al., 1998; Hall, 2004; Lauritsen et al., 2009; Popenoe, 1996). Although pressures and stressful events affect both males and females, the impact of family dysfunction and changes in the family structure (e.g., divorces, female-headed families) are greater for the young female. This is because females are more influenced by relationships within the family, and their mental and emotional wellbeing are more likely to rely on parental emotional support (Heimer \& De Coster, 1999; Steffensmeier et al., 2005). Furthermore, sexual abuse and harassment are key factors for understanding young female deviant and violent behavior (Artz, 1998; Chesney-Lind \& Shelden, 1992).

In a similar vein, the economic marginalization hypothesis contends that the rise in female violence results from the increase in economic hardships during the past two decades, and these specifically exacerbate the situation for uneducated and poor women. Thus, the socioeconomic disadvantage and distress that women are subject to are central determinants for understanding the rise in female violent offending across time (Baskin and Sommers, 1998; Heimer, 2000; Heimer et al., 2006: Lauritsen et al., 2009). Findings indicate that during periods of economic hardship and pressures, and when female unemployment rates are higher than those of men, the gender rate ratio of aggravated assault arrests also increases (Heimer et al., 2006). Moreover, young females who face multiple sources of marginalization (e.g., poor families, minority social groups, disorganized communities and limited educational background) are more likely to be involved in violent activities and join gangs (Artz, 1998; Chesney-Lind et al., 2008).

The policy-generated hypothesis proposes that arrest rates primarily reflect changes in crime control policy. Over the past three decades, control policy has shifted away from the penal-welfare model (based on a rehabilitative perspective) toward a more proactive and risk management policy (Feld, 2009; Steffensmeier et al., 2006). This "new culture of crime control," as termed by Garland (2001), has led to mass arrests and higher rates of imprisonment in the late 20th century (Beckett, 1997; Feld, 1999; Garland, 2001; Hogeveen, 2005). This policy has largely affected the juvenile justice system by inciting further accusations of youth violence. Moreover, it has led to an increase in young female 
involvement in the criminal justice system due to the subsequent lower thresholds of criminality and the criminalization of minor offences (Blumstein, 2000; Chesney-Lind \& Belknap, 2004; Irwin \& Chesney-Lind, 2008; Feld, 2009; Steffensmeier et al., 2005). As part of this policy of intolerance, there is a tendency to expand the definition of violence and blur the distinctions between different types of aggression that may manifest in interpersonal violence. Therefore, as the definitions of violence become more flexible and encompassing, the more likely that females will be charged with violence (Steffensmeier et al., 2005).

In addition, prevention programs and efforts to deal with juvenile delinquency are commonly aimed at reducing male violent offending. Indeed, young males are more likely to commit serious injury-producing violence in the public sphere, whereas the results of female violence are usually less serious and take place in private settings (Campbell, 1993; Kruttschnitt, Gartner and Ferraro, 2002). As a consequence of this strategy, male rates of violent offending may decline and lead to a narrowing of the gender gap. Another aspect relates to the policing of domestic violence, which also affects the numbers of female arrests. Although this policy originally aimed to protect women from violence, in effect it has led to an increase in their arrests. This is because when it is not clear who is the main aggressor in domestic violence cases, police practice is to arrest both the woman and her partner (Lauritsen et al., 2009; Young, 2002).

The discussion on the gender gap in violence provides mixed evidence. Analyses of time-series data in the United States between the years 1980 and 2003 from three sources, i.e., arrest data, the National Crime Victimization Survey, and self-reports, show that there are no significant changes in the gender gap in violent offending over time (Steffensmeier et al., 2005, 2006). In contrast, Lauristen, Heimer and Lynch (2009) examined patterns of violence from 1973 to 2005 and found that the gender gap is in fact closing over the years. Their study indicated that female-to-male offending rate ratios increased for simple assault, aggravated assault and robbery. The proportion of violent incidents committed by female offenders approximately doubled over the period under review. Furthermore, patterns of gender gap in the arrest data were very similar to those in the Victimization Survey data (Lauritsen et al., 2009). However, it is possible that the differences in the results of these two studies derived from using different methodological decisions and procedures for assessing female and male patterns of violence.

In summary, although the gender gap in violent offending has recently received wide scholarly attention, the debate about whether it is narrowing over time has not been resolved. The current study strives to add to the research knowledge by means of an analysis of gender gap trends in juvenile violent offending in Israel. Moreover, by examining gender variations associated with the age of offenders whose first criminal records were filed for violent offenses, the current study aims to provide a new insight into this field.

\section{Data and Research Strategy}

The study examines trends in juvenile violent crime from 1996 to 2012 (Note 1). The decision to analyze juvenile violent offending is based on the assumption that if there are changes in female violent behavior, they are more likely to be manifested among young 


\section{$\Lambda$ Macrothink}

females since they are more likely to adopt social changes in norms and gender-role expectations. Five offenses were used to measure changes in violent offending: simple assault, aggravated assault, knife possession, robbery, and homicide.

Data were obtained from the official statistics of the Israel Police and refer to criminal files that were opened due to crimes perpetrated by minors between ages 12 and 18, according to Israeli criminal law with respect to underage criminal responsibility (see Appendix 1 and 2). The data include information about the age of the offender's first violence-related criminal registration, which allowed us to investigate the trends regarding this aspect among females and males. An examination of this variable may provide us with a better understanding of whether there is a decrease in the age of young female involvement in criminal violent behavior over time. Prior to the analysis, the police administrative procedures (e.g., the policy to open criminal records for minors) were examined in order to ensure that no changes occurred during the time of the study, since it could have led to an increase or decrease in crime rates. However, no changes were found in the police procedures.

The assessment of gender-based violence was conducted in two stages. First, female and male rates of violent behavior were calculated according to an Israeli adolescent population ranging from age 12 to 18 for every year of the study period. Data of the general adolescent population were obtained from the Israel Central Bureau of Statistics. The gender gap trends in violence were estimated by employing the gender rate ratio strategy. The gender rate ratio is defined as the rate of female offending divided by the male rate of offending and is computed for each type of violent offence after adjusting for the sex and age composition of the population of each respective year (see Heimer, 2000; O'Brien, 1999). This strategy is based upon a previous study that analyzed gender gap trends in the United States using the same method (Lauritsen et al., 2009). Second, data analysis was conducted using a general linear regression model in order to check whether the differences in rates of violence over time were significant. The dependent variable was the difference between two consecutive values of rates of violence and the independent variables were a constant and time. Separate analyses were conducted for males and females and for each type of offence: simple assault, aggravated assault, knife possession, robbery, and homicide.

\section{Findings}

Plots and histograms were used to offer a visual representation of changes in female-to-male patterns of violence and gender gap trends. These graphical methods can provide a visual illustration of trends and help us understand, for example, whether variations in the gender gap resulted from a rise in female violence or a decrease in male violence. Figures 1 through 5 illustrate changes in male and female violent offending. 


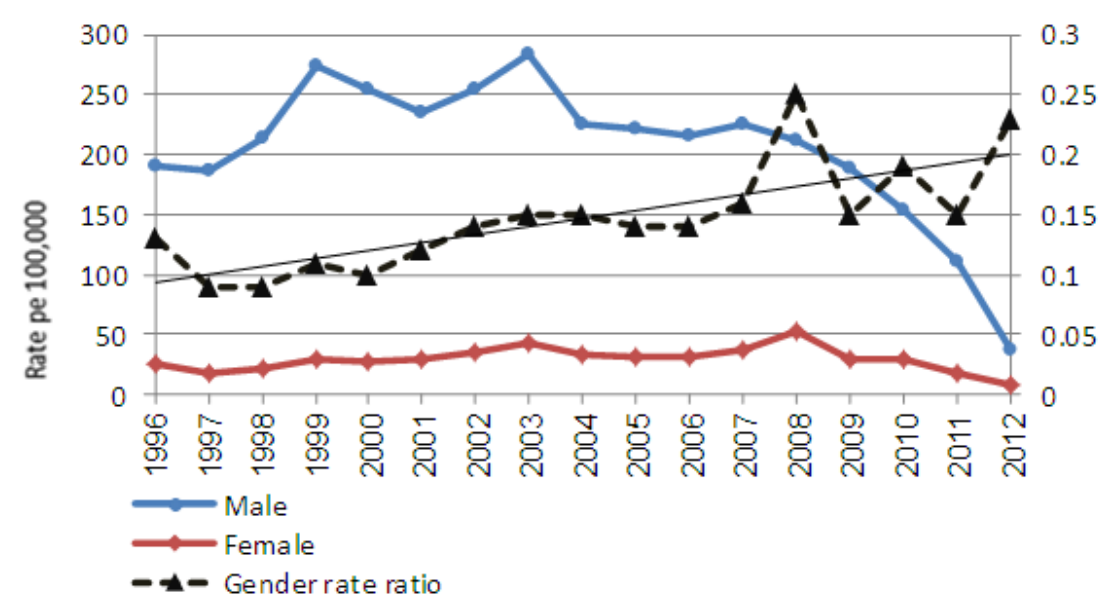

Figure 1. Simple assault offending by gender 1996-2012

Figure 1 presents the variations in female and male involvement in simple assault. As can be seen, there was an increase in male rates of simple assault, which reached a peak of 283.1 per 100,000 by the year 2003. Subsequently, male rates sharply declined and reached a low of 37.5 per 100,000 in 2012. Accordingly, between 1996 and 2012 there was a decrease of $80.1 \%$ in male rates of simple assault.

However, female simple assault rates dramatically increased and doubled from 26.4 to 53.7 per 100,000 between 1996 and 2008. In the following period, female rates dropped to a low of 8.7 per 100,000 in 2012 . The overall trend in female rates was a decrease of $68 \%$ between 1996 and 2012. The inspection of figure 1 shows an increase of the gender rate ratio by $77 \%$ over the study period. This rise mainly resulted from the decline in male rates, which was greater than the decline in female rates.

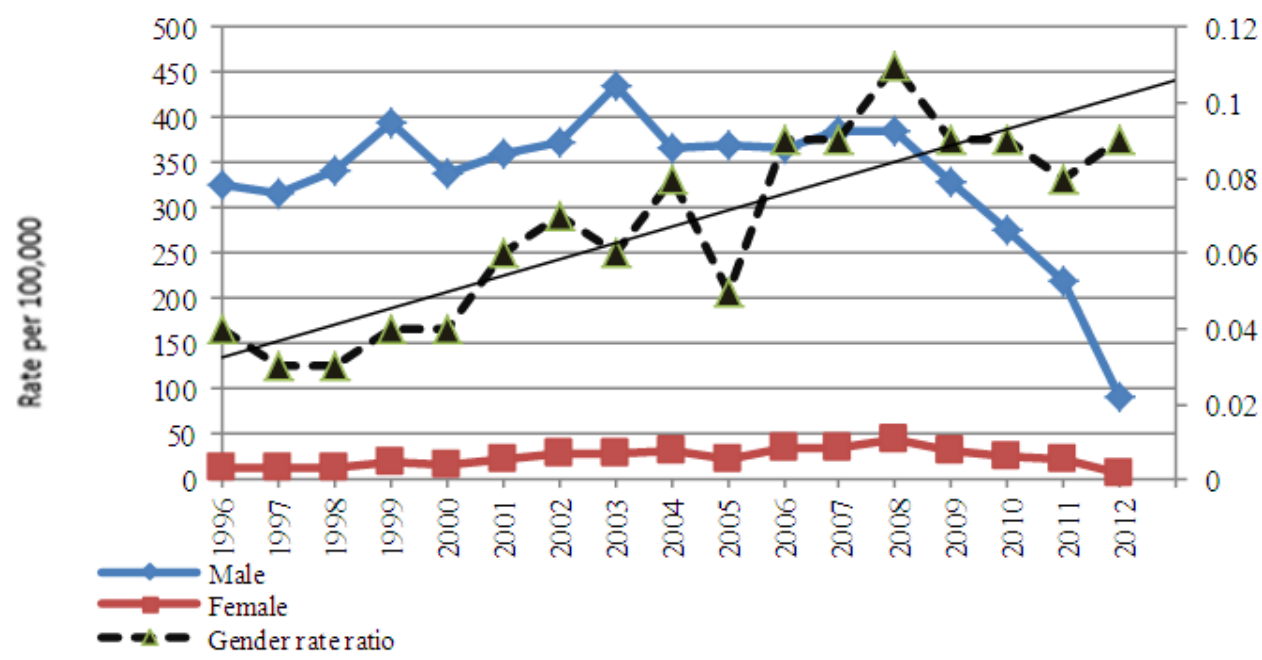

Figure 2. Aggravated assault offending by gender 1996-2012 


\section{Macrothink Institute ${ }^{\text {TM }}$}

Figure 2 shows trends in male and female rates for aggravated assault. The findings indicate that male rates increased and reached a peak of 434.9 per 100,000 by the year 2003 and remained at a high level until the year 2008. Subsequently, there was a sharp decline to 92.5 per 100,000 in 2012 . Thus, over the study period there was a decrease of $71.8 \%$ in male rates of aggravated assault.

An examination of the trends of female rates shows a remarkable increase from 13.2 in 1996 to 44.8 per 100,000 in 2008 . However, following this period there was a sharp decrease. In contrast, there was an increase in the gender rate ratios of aggravated assault. The findings indicate that the decrease in male rates was 1.7 times greater than the decline in female rates. Hence, the narrowing of the gender gap in aggravated assault was largely a function of the sharp drop in male rates of offending.

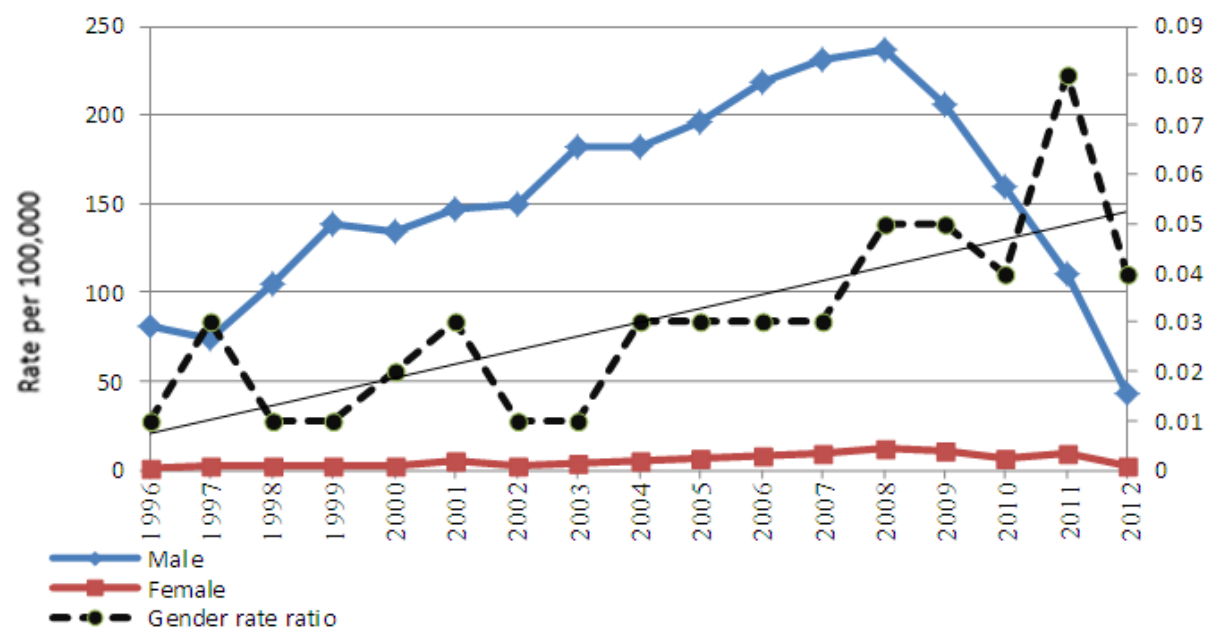

Figure 3. Knife possession offending by gender 1996-2012

Figure 3 displays trends in male and female rates for knife possession. As can be viewed, male rates increased and reached a high of 237 per 100,000 by 2008 . However, following this period there was a decline to the lowest level of 43.3 per 100,000 in 2012 . So, the overall trend of male rates was defined by a decrease of $47 \%$. In a similar vein, female rates for knife possession markedly increased between 1996 and 2008 (from 1.39 to 12.22 per 100,000), but in the subsequent period there was a decline.

Thus, the overall change in female rates was an increase of $35.2 \%$ during the study period. In addition, the figure clearly demonstrates a general upward movement in the rate ratios for knife possession over the years. 


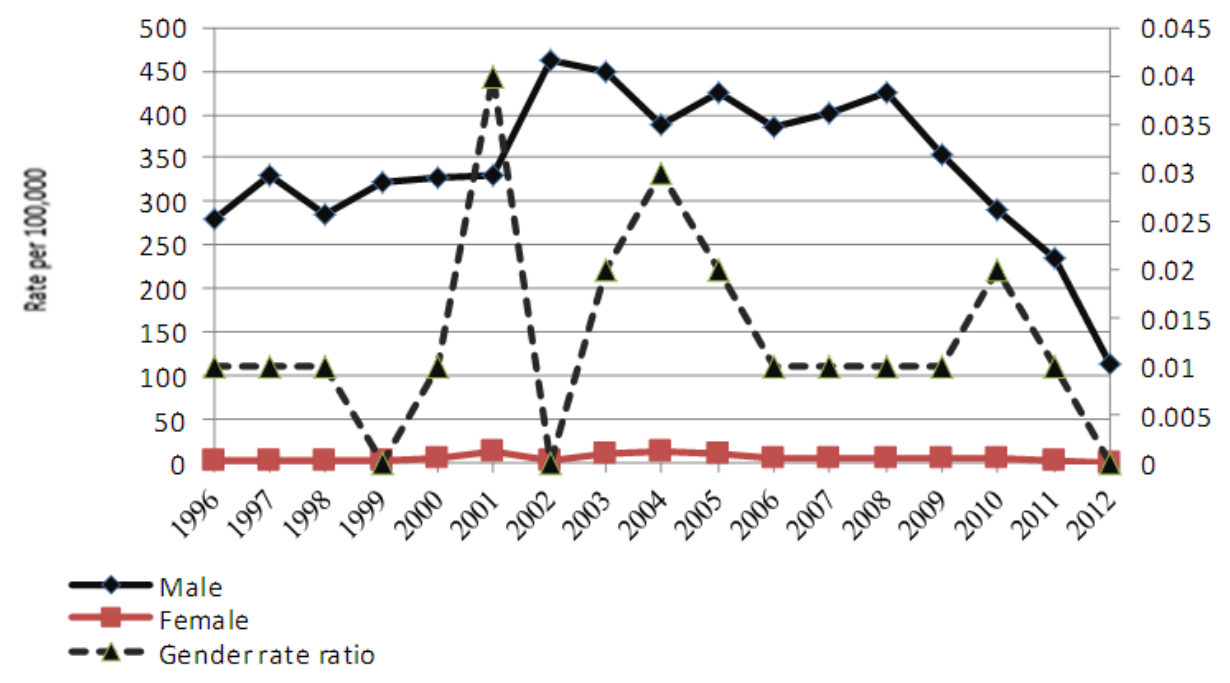

Figure 4. Robbery offending by gender 1996-2012

Figure 4 shows gender trends for robbery. The findings indicate that male rates increased and reached a highest level of 461 per 100,000 by the year 2008. Subsequently, there was a sharp decline. Overall, there was therefore a decrease in male robbery offending of $75.2 \%$ during the study period. The findings indicate that female rates of robbery offending are generally very low and revolved around 4 per 100,000. A review of robbery rate ratios demonstrates sharp fluctuations mainly between 2001 and 2005, and general tendency of minor decline over time.

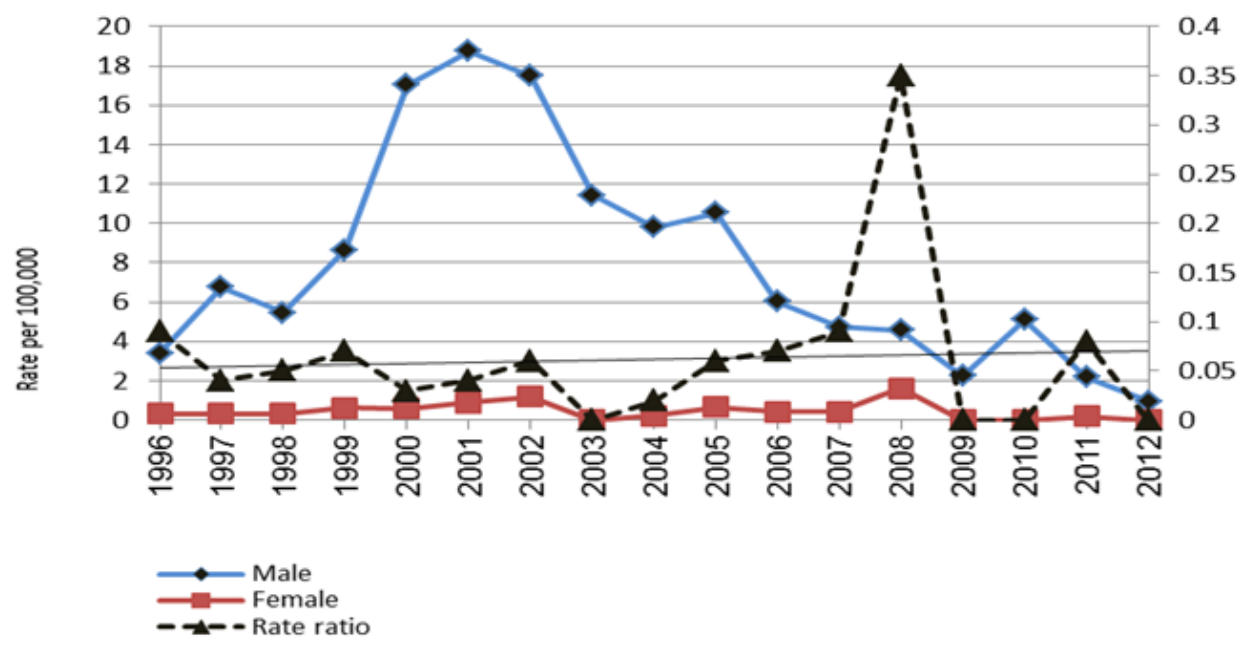

Figure 5. Gender trends for homicide 1996-2012

Figure 5 presents the variations in homicide. The graph reveals that male rates increased and 


\section{Macrothink Institute ${ }^{\mathrm{TM}}$}

reached a peak of 18.7 per 100,000 by 2001 and in subsequent years there was a decline. So, the general trend for male homicide was a decrease of $98.3 \%$ over the study period. As for female homicide, the rates are very low and revolved around 0.4 per 100,000 over the years. Yet, the findings indicate fluctuations in the rate ratios and a very slight increase throughout the series. The results for homicide and robbery suggest that as the violent crime becomes more infrequent, the greater the degree of fluctuation in offending trends.

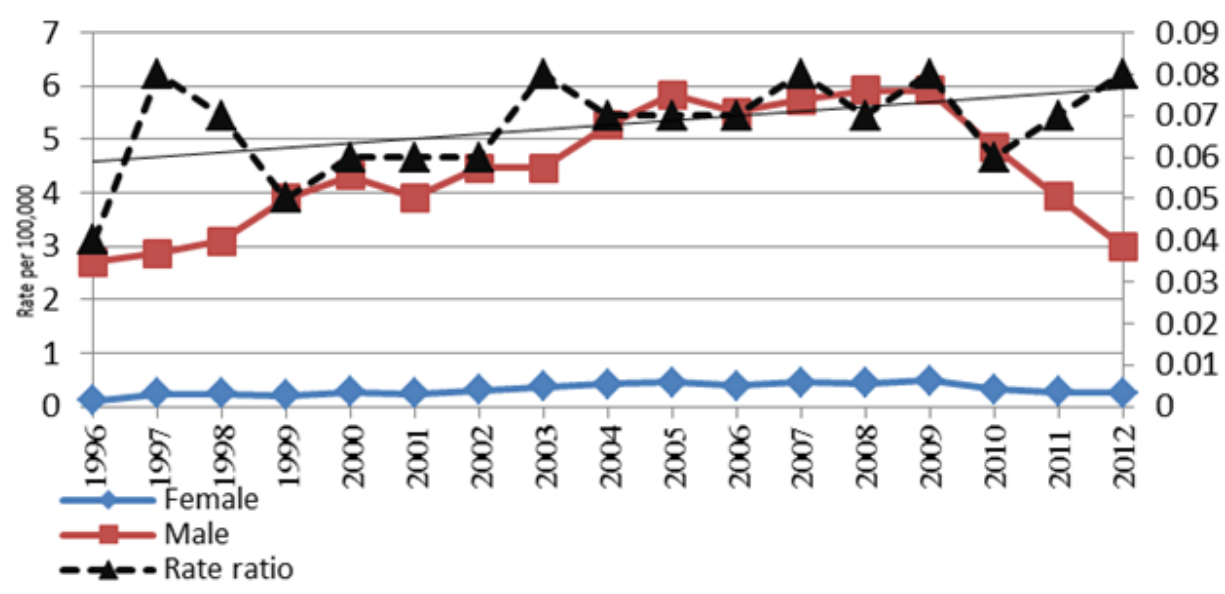

Figure 6. Gender rates of young minors (ages 12-14 years) for a violent offence

The trends in Figure 6 portray gender rates of young minors (ages 12-14 years) who received their first criminal record in violent offending. The figure shows that young male rates increased and reached a high level between the years 2005 and 2009 of 5.92 per 100,000. However, there was a sharp decline in subsequent years. In a similar vein, female rates rose between 2005 and 2009 and then dropped. Surprisingly, the overall trend shows that young female rates in violence increased by $136 \%$, whereas male rates increased by $10.3 \%$ during this time. In other words, the notable decrease in the age of female involvement in violent crime is significantly greater than the decline in the age of male involvement in violent crime. As a result, the general tendency of the gender gap in this aspect has narrowed over the years. Table 1 presents the results of the regression models coefficients for violent offending. 
Table 1. Summary of regression models coefficients for juvenile violent offending

\begin{tabular}{|c|c|c|c|c|c|}
\hline Offense & Gender & $\beta$ & $S E$ & $\mathrm{~N}$ & $R^{2}$ \\
\hline \multirow[t]{2}{*}{ Simple Assault } & Male & $-0.63 * *$ & 1.47 & 16 & 0.4 \\
\hline & Female & 0.02 & 0.52 & 16 & 0.0 \\
\hline \multirow{2}{*}{ Aggravated Assault } & Male & $-0.58 * *$ & 2.29 & 16 & 0.34 \\
\hline & Female & 0.4 & 0.47 & 16 & 0.16 \\
\hline \multirow[t]{2}{*}{ Knife Possession } & Male & $-0.69 * *$ & 1.23 & 16 & 0.48 \\
\hline & Female & 0.66 & 0.13 & 16 & 0.44 \\
\hline \multirow[t]{2}{*}{ Robbery } & Male & -0.36 & 0.92 & 16 & 0.13 \\
\hline & Female & -0.23 & 0.05 & 16 & 0.05 \\
\hline \multirow[t]{2}{*}{ Homicide } & Male & -0.23 & 0.39 & 16 & 0.15 \\
\hline & Female & -0.23 & 0.02 & 16 & 0.03 \\
\hline
\end{tabular}

The findings in Table 1 indicate that there are significant downward trends in male rates of simple assault $(\beta=-0.63, p=0.0)$, aggravated assault $(\beta=-0.58, p=0.0)$ and knife possession $(\beta=-0.69, p=0.0)$. In contrast, no significant upward or downward trend was found for male robbery and homicide offences. Furthermore, the results in Table 1 show that no significant changes were found in female violence.

\section{Discussion and Conclusions}

Researchers have paid more attention to the gender gap in the perpetration of violence in recent years. Indeed, there is growing evidence that female rates of nonlethal violence increased during the 1990s. Nevertheless, the debate about whether the gender gap in violence is closing is ongoing. As mentioned, some scholars have observed that the gender gap is in fact closing over time, whereas other researchers contend that the gender gap is mostly stable (Heimer, 2000; Lauristen et al., 2009; O’Brien, 1999; Steffensmeier, 1993; Steffensmeier et al., 2005, 2006). However, it is feasible that changes in female patterns of violent offending might be manifested primarily among the younger generation.

The current study addresses this important issue by examining recent gender trends in juvenile violent offending in Israel. Several findings were particularly noteworthy.

First, the analysis of our findings indicates that female-to-male offending rate ratios have increased over the study period (i.e., 1996-2012) for simple assaults, aggravated assault and carrying a knife. These findings confirm the hypothesis that the gender gap is narrowing over time. Nevertheless, the analysis reveals that there are significant downward trends in male rates of simple assault, aggravated assault and knife possession over the years. These results suggest that the closing of the gender gap in simple assault, aggravated assault, and knife possession is largely a function of the decline in male violence. 
Second, these gender gap trends are compatible with previous research that analyzed male and female patterns of violence in the United States. The present study has shown that the narrowing in the gender gap mainly resulted from decreases in male offending (Lauristen et al., 2009). Thus, it seems that similar trends have led to the reduction of the gender gap both in the United States and Israel. These patterns may strengthen the conclusion that the narrowing of the gender gap in nonlethal violence in recent years mostly reflects the decline in male offending rather than a rise in female violence.

Third, no substantial changes were found in the gender gap for robbery and homicide, although there were sharp fluctuations over the years. The preponderance of the violence perpetrated by females is only marginally associated with serious or injury-producing crimes, which are largely confined to male offending (Lauriston et al., 2009; Steffensmeier et al., 2005, 2006). Thus, it may be suggested that the more serious and grave the crime, the greater probability that the gender gap will remain stable over time.

Fourth, the current study provides a new insight into the analysis of these issues by examining female and male rates of violence among young minors (ages 12-14 years) who had their first violence-related criminal record filed against them. The analysis indicates that young female-to-male offending rate ratios have increased over the study period. Furthermore, the closing of the gender gap among young minors has largely resulted from the increase in female rates of offending, which was greater than the rise in male rates of offending. These findings raise the question whether there is a genuine trend in young female behavior toward more violence or do the findings simply reflect informal changes in police practices?

In line with the liberation hypothesis, one may suggest that changes in gender roles have led young females to adopt male patterns of violent behavior, which in turn have reduced the gender gap. However, the findings do not provide strong evidence to support this hypothesis, since in regard to most violence offenses there was a decrease in female rates of offending.

Another possible explanation for the narrowing of the gender gap relates to changes in crime control policy. In this context, it has been argued that it is "the cumulative effect of the policy shifts, rather than a change in girls' behavior toward more violence, that accounts for their higher arrest rates and the narrowing gender gap" (Steffensmeier et al., 2006; p. 96). Therefore, even though there were no official changes in criminalization policy during the study period, it is possible that unofficial changes may have taken place, such as intolerant attitudes toward young female violence, which led to the tapering gender gap. However, further inquiry is needed to address this aspect.

Our research, of course, is not without its limitations. This study restricted its analysis to a relatively short period of time $(n=16)$. The results implying the closing of the gender gap clearly indicate that further research is required. Expanding the analysis to victimization data or self-report data will enhance existing knowledge on patterns of violent behavior among young female adolescents. Furthermore, we need to shift attention away from the possibly biased databases of the criminal justice system to other economic or community resource variables and prevention programs that may be responsible for the narrowing of the gender gap. 


\section{References}

Adler, F. (1975). Sisters in Crime. New York: McGraw-Hill.

Agnew, R. (1992). Foundation for a general strain theory of crime and delinquency. Criminology, 30, 47-87. http://dx.doi.org/10.1111/j.1745-9125.1992.tb01093.x

Agnew, R., \& White, H. R. (1992). An empirical test of general strain theory. Criminology, 30, 475-499. http://dx.doi.org/10.1111/j.1745-9125.1992.tb01113.x

Almgren, G. (1998). Joblessness, family disruption, and violent deaths in Chicago: 1970-1990. Social Forces, 76, 1465-1493. http://dx.doi.org/10.1093/sf/76.4.1465

Artz, S. (1998). Sex, Power, and the Violent School Girl. Toronto, Canada: Trifolium.

Baskin, D. R., \& Sommers, I. B. (1998). Casualties of Community Disorder. Boulder, Colorado: Westview Press.

Beckett, K. (1997). Making Crime Pay: Law and Order in Contemporary American Politics. New York: Oxford University Press.

Blumstein, A. (2000). The recent rise and fall of American violence. In A. Blumstein, \& J. Wallman (Eds.), The Crime Drop in America. New York: Cambridge University Press.

Bricknell, S. (2008). Trends in violent crime. Trends and Issues in Crime and Criminal Justice, no. 359. Canberra: Australian Institute of Criminology.

Chesney-Lind, M., \& Shelden, R. G. (1992). Girls, Delinquency and Juvenile Justice. Belmont, CA: Wadsworth.

Chesney-Lind, M., \& Irwin, K. (2008). Beyond Bad Girls: Gender, Violence and Hype. New York: Routledge.

Chesney-Lind, M. (2004). Girls and Violence: Is the Gender Gap Closing? VAWNET Applied Research Forum. Philadelphia: National Resource Center on Domestic Violence.

Chesney-Lind, M., \& Shelden, R. G. (2004). Girls, Delinquency, and Juvenile Justice. Belmont, CA: Wadsworth.

Eggen, A. Th. J., van der Laan, A. M., Engelhard, B. J. M., Blom, M., Broeders, A. P. A., \& Bogaerts, S. (2005). Criminaliteit en opsporing [criminality and detection]. In A. Th. J. Eggen \& W. van der Heide (Ed.), Criminaliteit en Rechtshandhaving: Ontwikkelingen en Samenhangen (pp. 89-128). The Hague, Netherlands: WODC (Dutch).

Feld, B. C. (1998). Juvenile and criminal justice system's responses to youth violence. Crime \& Justice: An Annual Review, 24, 189-261. http://dx.doi.org/10.1086/449280

Feld, B. C. (2009). Violent girls or relabeled status offenders? An alternative interpretation of the data. Crime Delinquency, 55, 241-265. http://dx.doi.org/10.1177/0011128708330629

Garland, D. (2001). The Culture of Control: Crime and Social Order in Contemporary Society. Chicago: The University of Chicago Press. 


\section{Macrothink

Gavazzi, S. M. (2006). Global risk indicators and the role of gender in a juvenile detention sample. Criminal Justice and Behavior, 33, 597-612. http://dx.doi.org/10.1177/0093854806288184

Hall, W. (2004). Violence among girls on upswing. The Patriot News (April 21, pp. A1, A8).

Heimer, K. (2000). Changes in the gender gap in crime and women's economic marginalization. In G. LaFree (Ed.), Nature of Crime: Continuity and Change. Washington, DC: United States Department of Justice.

Heimer, K., \& De Coster, S. (1999). The gendering of violent delinquency. Criminology, 37(2), 277-312. http://dx.doi.org/10.1111/j.1745-9125.1999.tb00487.x

Heimer, K. et al. (2006). Crimes of poverty: Economic marginalization and the gender gap in crime. In K. Heimer, \& C. Kruttschnitt (Eds.), Gender and Crime: Patterns of Victimization and Offending. New York: New York University Press.

Hogeveen, B. R. (2005). If we are tough on crime, if we punish crime, then people get the message. Constructing and governing the punishable young offender in Canada during the late 1990s. Punishment \& Society, 7, 73-89. http://dx.doi.org/10.1177/1462474505048134

Irwin, K., \& Chesney-Lind, M. (2008). Girls' violence: Beyond dangerous masculinity. Sociology Compass, 837-855. http://dx.doi.org/10.1111/j.1751-9020.2008.00120.x

Kruttschnitt, C., Gartner, R., \& Ferraro, K. (2002). Women's involvement in serious interpersonal violence. Aggression and Violent Behavior, 7, 529-565. http://dx.doi.org/10.1016/S1359-1789(01)00045-3

Lauritsen, J. L., Heimer, K., \& Lynch, J. P. (2009). Trends in the gender gap in violent offending: New evidence from the National Crime Victimization Survey. Criminology, 47, 361-399. http://dx.doi.org/10.1111/j.1745-9125.2009.00149.x

Morse, J. (2002). Women on a binge. Time (April 1, pp. 57-61).

O'Brien, R. (1999). Measuring the convergence/divergence of "serious crime" arrest rates for males and females: 1960-1995. Journal of Quantitative Criminology, 25, 97-114. http://dx.doi.org/10.1023/A:1001834210816

Popenoe, D. (1996). Life without Father. New York: The Free Press.

Schaffner, L. (1999). Violence and female delinquency: Gender transgressions and gender invisibility. Berkeley Women's Law Journal, 14, 40-65.

Sela-Shayovitz, R. (2009). Social control in the face of security and minority threats: The effects of terrorism, minority threat, and economic crisis on the law enforcement system in Israel. The British Journal of Criminology, 49(6), 772-787. http://dx.doi.org/10.1093/bjc/azp037

Simon, R. J. (1975). Women and Crime. Lexington, MA: Lexington Books.

Smart, C. (1976). Women, Crime and Criminology. London: Routledge \& Kegan Paul. 
Steffensmeier, D. (1993). National trends in female arrests: 1960-1990: Assessments and recommendations for research. Journal of Quantitative Criminology, 9, 411-441. http://dx.doi.org/10.1111/j.1745-9125.1993.tb01136.x

Steffensmeier, D. (2005). An assessment of recent trends in girls' violence using diverse longitudinal sources. Is the gender gap closing? Criminology, 43, 355-406. http://dx.doi.org/10.1111/j.0011-1348.2005.00011.x

Steffensmeier, D., Zhong, H., Ackerman, J., Schwartz, J., \& Agha, S. (2006). Gender gap trends for violent crimes, 1980-2003. Feminist Criminology, 1, 72-98. http://dx.doi.org/10.1177/1557085105283953

\section{Notes}

Note 1. The period under examination began in January, 1996, since it was not possible to obtain data relating to juvenile offending prior to that year.

Appendix 1: Annual Juvenile Males Criminal Files in Violence (numbers)

\begin{tabular}{cccccc}
\hline Year & Simple Assault & Aggravated Assault & Knife Possession & Robbery & Homicide \\
\hline 1996 & 555 & 958 & 228 & 279 & 10 \\
1997 & 606 & 1030 & 242 & 329 & 22 \\
1998 & 702 & 1123 & 344 & 285 & 18 \\
1999 & 915 & 1318 & 464 & 322 & 29 \\
2000 & 865 & 1154 & 455 & 328 & 58 \\
2001 & 801 & 1234 & 504 & 330 & 64 \\
2002 & 891 & 1297 & 524 & 461 & 61 \\
2003 & 992 & 1524 & 636 & 450 & 40 \\
2004 & 1059 & 1718 & 851 & 388 & 46 \\
2005 & 1050 & 1758 & 933 & 424 & 50 \\
2006 & 1038 & 1757 & 1048 & 386 & 29 \\
2007 & 1089 & 1869 & 1124 & 402 & 23 \\
2008 & 1019 & 1860 & 1140 & 426 & 22 \\
2009 & 917 & 1594 & 999 & 353 & 11 \\
2010 & 750 & 1353 & 779 & 290 & 25 \\
2011 & 561 & 1099 & 555 & 234 & 11 \\
2012 & 197 & 485 & 227 & 114 & 5 \\
\hline
\end{tabular}




\section{Al Macrothink}

Journal of Social Science Studies

ISSN 2329-9150

2017, Vol. 4, No. 1

Appendix 2: Annual Juvenile Females Criminal Files in Violence (numbers)

\begin{tabular}{cccccc}
\hline Year & Simple Assault & Aggravated Assault & Knife Possession & Robbery & Homicide \\
\hline 1996 & 76 & 38 & 4 & 3 & 1 \\
1997 & 55 & 38 & 8 & 4 & 1 \\
1998 & 66 & 39 & 6 & 4 & 1 \\
1999 & 98 & 60 & 6 & 3 & 2 \\
2000 & 89 & 49 & 9 & 5 & 2 \\
2001 & 99 & 75 & 17 & 15 & 3 \\
2002 & 120 & 94 & 7 & 2 & 4 \\
2003 & 144 & 102 & 11 & 10 & 0 \\
2004 & 153 & 143 & 26 & 14 & 1 \\
2005 & 142 & 98 & 30 & 11 & 3 \\
2006 & 142 & 157 & 37 & 5 & 2 \\
2007 & 172 & 165 & 40 & 6 & 2 \\
2008 & 198 & 165 & 45 & 5 & 6 \\
2009 & 139 & 145 & 51 & 5 & 0 \\
2010 & 137 & 121 & 32 & 7 & 0 \\
2011 & 91 & 109 & 46 & 3 & 1 \\
2012 & 51 & 49 & 11 & 0 & 0 \\
\hline
\end{tabular}

\section{Copyright Disclaimer}

Copyright for this article is retained by the author(s), with first publication rights granted to the journal.

This is an open-access article distributed under the terms and conditions of the Creative Commons Attribution license (http://creativecommons.org/licenses/by/3.0/). 